\section{Increasing Plant Density in Eastern United States Broccoli Production Systems to Maximize Marketable Head Yields}

\author{
Brian Ward ${ }^{1,4,7}$, Powell Smith ${ }^{2,5}$, Susan James ${ }^{2,5}$, \\ Zachary Stansell ${ }^{3,6}$, and Mark Farnham ${ }^{3,6}$
}

AdDitional INDEX WORDs. Brassica olevacea, plant spacing, plant population

SUMMARY. Increased demand for fresh market crown-cut broccoli (Brassica olevacea var. italica) has led to increased production along the eastern seaboard of the United States. Maximizing broccoli yields is a primary concern for quickly expanding eastern markets. Thus, a plant density study was carried out in Fall 2012 and 2013 using the hybrid cultivar Emerald Crown on a commercial farm in Summerton, SC, and in Fall 2013 using 'Emerald Crown' and another hybrid, 'Durapak 19', on a research farm in Charleston, SC. The objective was to determine the effect of variable within-row spacings of 4, 6 , and 8 inches (using a system with double rows spaced 12 -inches apart) on marketable yields and quality in the three environments. Our results indicated that increasing plant density by reducing within-row spacing to 4 inches significantly increased overall yield per hectare over the 6- and 8-inch spacing treatments at two of three environments. Stem diameter and average head weight were unaffected by plant density; however, heads harvested from plots with the highest plant densities had significantly $(P<0.01)$ lower bead uniformity in the Summerton 2012 trial, and significantly $(P<0.05)$ larger bead size in the two trials conducted in 2013. In general, the highest total marketable yields were from the 4 -inch within-row spacing, but increased competition at the highest density may increase the risk of plants producing heads with lower quality characteristics. With the increased risk of producing lower quality marketable heads along with the increased production costs associated with the 4 -inch spacing, yield and head quality attributes may be optimized at the 6 -inch within-row spacing.

$\mathrm{U}$ S. commercial broccoli production has been dominated by California producers since the 1960s [U.S. Department of Agriculture (USDA), 2014]. California has been able to supply year-round broccoli throughout the United States by shifting production locations during the year. The desert areas of

The cost of publishing this article was defrayed in part by the payment of page charges. Under postal regulations, this article, therefore, must be hereby marked advertisement solely to indicate this fact.

This research was partially funded by a U.S. Department of Agriculture-National Institute of Food and Agriculture-Specialty Crops Research Initiative grant entitled "Developing an Eastern Broccoli Industry."

${ }^{1}$ Department of Horticulture, Clemson University Coastal Research and Education Center, 2700 Savannah Highway, Charleston, SC 29414

${ }^{2}$ Clemson University Cooperative Extension, Lexington County Extension Center, Lexington, SC 29072

${ }^{3}$ U.S. Vegetable Laboratory, U.S. Department of Agriculture, Agricultural Research Service, 2700 Savannah Highway, Charleston, SC 29414

${ }^{4}$ Research Specialist

${ }^{5}$ Regional Lead Extension Associate and Field Specialist II

${ }^{6}$ Biological Science Technician and Research Geneticist

${ }^{7}$ Corresponding author. E-mail: bw@clemson.edu. the state, along with nearby production areas in Arizona, have historically supplied product through winter, the Central Valley has supplied product in spring and fall, and coastal valleys (e.g., Salinas Valley) supply heads in summer. In recent decades, eastern growers have attempted commercial production of broccoli, and in some states (e.g., Florida and Maine) significant acreage of the crop is under cultivation every year. Although eastern environments are not conducive to year-round broccoli production, most areas have specific seasons (e.g., late fall in South Carolina or late summer in upstate New York) when market-quality broccoli heads can be produced. With this in mind, a multi-institutional collaborative effort was initiated in 2010 [National Institute of Food and Agriculture (NIFA) project no. 2010-51181-21062, Specialty Crop Research Initiative] to identify appropriate broccoli cultivars and cultural practices that could be used in eastern states to make broccoli production in that region more competitive with western production systems. Early in this effort, we proposed that it is especially important to test increased population densities combined with the use of contemporary broccoli hybrids as a method to optimize marketable yield.

South Carolina broccoli production exemplifies production in many eastern states in that growers plant up to $\approx 50,000$ plants $/$ ha and yield up to $\approx 10,000 \mathrm{~kg} \cdot \mathrm{ha}^{-1}$ or more (Atallah and Gomez, 2013). On the contrary, Californian growers plant up to 172,000 plants/ha and yield up to 20,000 $\mathrm{kg} \cdot \mathrm{ha}^{-1}$. There are a limited number of earlier research trials examining the effects of variable broccoli plant densities on head production, and those that are available are older and describe the use of cultivars or hybrids no longer used (Cutcliffe, 1971, 1975). Chung (1982) conducted plant density studies in Australia using older broccoli cultivars and concluded that densities approaching 200,000 plants/ha reached an asymptotic yield limit of 11,000 $\mathrm{kg} \cdot \mathrm{ha}^{-1}$. Chung (1982) also concluded that similar yields were attained using lower plant densities; however, he evaluated harvested heads that were small (e.g., $\leq 2$ inches diameter), and only suitable for bunching. Dufault and Waters (1985) conducted plant density studies in Minnesota. They showed that plant densities of 72,000 plants/ha resulted in increased yields of $10,000 \mathrm{~kg} \cdot \mathrm{ha}^{-1}$ but also a significant reduction in mean head weight, making harvested heads only suitable for bunching. Based on these results, Dufault and Waters (1985) concluded that a density of 35,000 plants/ha was

\begin{tabular}{llll}
\hline $\begin{array}{l}\text { Units } \\
\text { To convert U.S. to SI, } \\
\text { multiply by }\end{array}$ & U.S. unit & SI unit & $\begin{array}{l}\text { To convert SI to U.S., } \\
\text { multiply by }\end{array}$ \\
\hline 0.4047 & acre(s) & $\mathrm{ha}$ & 2.4711 \\
9.3540 & gal/acre & $\mathrm{L} \cdot \mathrm{ha}^{-1}$ & 0.1069 \\
2.54 & inch(es) & $\mathrm{cm}$ & 0.3937 \\
25.4 & inch $(\mathrm{es})$ & $\mathrm{mm}$ & 0.0394 \\
1.1209 & lb/acre & $\mathrm{kg} \cdot \mathrm{ha}^{-1}$ & 0.8922 \\
0.0254 & mil & $\mathrm{mm}$ & 39.3701 \\
28.3495 & $\mathrm{oz}$ & $\mathrm{g}$ & 0.0353
\end{tabular}


optimal. By the mid-1990s, Californian growers were experimenting with plant densities as high as 150,000 plants/ha (USDA, 1999), and by 2010, plant densities greater than 100,000 plants/ ha were routinely used in western production (Le Strange et al., 2010).

Virginia researchers (Jett et al., 1995 ) investigated plant densities ranging from 36,000 to 108,000 plants/ha using within-row spacing of 6 to 18 inches in single or double row arrangements on beds, using the hybrid 'Brigadier'. They found that 36,000 plants/ ha and 18-inch within-row spacing using a twin row arrangement gave highest yields of relatively large (e.g., 8 inches diameter), single crown-type heads (Jett et al., 1995). Jett et al. (1995) found no significant effect of plant density on days to harvest in a 1990 trial, but observed that days to harvest was up to $9 \mathrm{~d}$ later with a density of 108,000 plants/ha compared with that of 36,000 plants/ha in a 1991 trial. In another Virginia study, Schellenberg et al. (2009) examined plant densities ranging from 18,000 to 48,000 plants/ha and within-row spacing of 9 to 24 inches, respectively, using the more modern hybrid 'Gypsy' as well as the older 'Everest' in a plasticulture system. This study found that 'Gypsy' was the preferred cultivar using a plant density of 35,000 plants/ha, yielding $11,500 \mathrm{~kg} \cdot \mathrm{ha}^{-1}$.

Consumption of broccoli has increased dramatically since the 1960 s and this trend is likely to continue (Farnham and Grusak, 2014). In addition, there are additional economic and environmental pressures, such as the increasing demand for local produce, the need to reduce carbon dioxide emissions, increased transportation costs, and other issues, which are likely to provide incentives for increasing broccoli production in eastern states. Because of these pressures, eastern broccoli growers are incentivized to maximize yields while maintaining quality-related standards. Our objective was to examine the effects of variable plant densities on yield and quality attributes of crown-cut broccoli produced in different environments using three different production systems used by South Carolina growers.

\section{Materials and methods}

Trials were conducted in three South Carolina environments over 2 years using the broccoli hybrid 'Emerald
Crown' (Sakata, Morgan Hill, CA). The first and second trials were on a commercial farm in Summerton, SC, in 2012 and 2013. A third trial was conducted at the Clemson Coastal Research and Education Center in Charleston, SC, in 2013. The Summerton trials were conducted on soils classified as Marlboro loamy sand (Thermic Typic Endoaqualfs), whereas the soil at Charleston is a Yonges loamy fine sand (Thermic Typic Endoaqualfs). A second, newly released hybrid 'Durapak 19' (Syngenta Seeds, Minnetonka, MN) was added to the Charleston trial in Fall 2013 to determine if observations were consistent with more than one modern cultivar.

A randomized complete block design with four replications was used for all trials. In the Summerton environment during Fall 2012, beds with centers spaced 6 -ft apart, were shaped, pressed, and mulched with conventional white 1 -mil polyethylene mulch film (Pliant Corp., Schaumburg, IL) and bed top width was 32 inches. Aqua-Traxx ${ }^{\circledR}$ PC 5/8-inch drip tape (Toro Co., El Cajon, CA) with emitters every 12 inches was laid just below the surface of the plastic mulch. This system was used to grow a primary crop of watermelon (Citrullus lanatus var. lanatus) during the summer before the broccoli experiment. Once the crop was harvested, the foliage was chemically desiccated, vines were removed, and 4-week-old broccoli transplants were planted onto the beds on 29 Aug. 2012. Weeds were controlled manually and with herbicides including the following: preemergent s-metachlor (Syngenta Corp., Greensboro, NC) applied at a rate of 1.06 $\mathrm{L} \cdot \mathrm{ha}^{-1}$ and spot-sprayed with a $4 \%$ glyphosate solution (Monsanto Co., St. Louis, MO). Liquid fertilizers were added daily by drip irrigation at a rate of $2.5 \mathrm{~kg} \cdot \mathrm{ha}^{-1}$ per day of $7 \mathrm{~N}-0 \mathrm{P}-5.3 \mathrm{~K}$. The 4-week-old transplants grown in 200 -cell flats with cell sizes of 1 -inch square $\times 3$-inches deep under standard commercial practices were arranged in two rows 12-inches apart, and three within-row spacings were used, including 4, 6, and 8 inches. Experimental plots were three beds wide and 12 - $\mathrm{ft}$ long and only the center bed was used for data collection. A 5 - $\mathrm{ft}$ withinrow buffer area was set between treatment plots. Heads were rated on a $1-5$ scale for bead size and bead uniformity based on a broccoli evaluation scale developed by the Eastern Broccoli Project (Farnham et al., 2011). For bead size rating, 1 indicates bead size greater than $1.75 \mathrm{~mm}$ diameter, 3 indicates 1.25 to $1.5 \mathrm{~mm}$ diameter, and 5 is less than $1.0 \mathrm{~mm}$ diameter. For bead uniformity, $1=$ very poor uniformity, $3=$ average to good uniformity, and $5=$ excellent uniformity. Heads were considered marketable if scored $\approx 3.0$ or greater (Farnham et al., 2011). As plants approached maturity, the center section was observed three times weekly for mature marketable heads that were 4 to 5 inches in diameter. All heads that attained this size and were rated as marketable were cut from the center plot section and counted, and a total sample of 20 of these heads were selected at random and graded to determine mean head characteristics for each treatment. Stems were cut $16 \mathrm{~cm}$ from the top of the head, the entire head was weighed and stem diameter was measured at the base of the cut stem using a digital caliper. Using the total number of heads harvested, percentage of marketable heads and total marketable yield were computed. The number of plants in each plot making nonmarketable heads was factored into the final computations.

Experimental conditions in the Charleston 2013 environment were similar to those in Summerton 2012 with the following differences: 1 ) beds were prepared specifically for the broccoli trial; there was no watermelon crop preceding the trial; 2) fertilization was achieved with preplant incorporation of $138 \mathrm{~kg} \cdot \mathrm{ha}^{-1} 15 \mathrm{~N}-0 \mathrm{P}-12.5 \mathrm{~K}$ along with drip irrigation and fertigation using an average rate of $1.5 \mathrm{~kg} \cdot \mathrm{ha}^{-1}$ per day $20 \mathrm{~N}-8.8 \mathrm{P}-16.6 \mathrm{~K}$, which was delivered three times a week. Transplants were planted on 13 Sept. 2013. Data collection was conducted as described for Summerton 2012. Simultaneous to conducting plots with 'Emerald Crown', plots of the hybrid 'Durapak 19' were randomized within the same trial and also evaluated under the same cultural practices and spacing treatments.

A Summerton Fall 2013 trial was intended as a more direct comparison with California production standards. Unmulched raised beds were formed with centers 3 -ft apart, with double rows of 'Emerald Crown' transplants on 29 Aug. 2013. Fertilization was accomplished with preplant incorporation 
of $54 \mathrm{~kg} \cdot \mathrm{ha}^{-1} 6 \mathrm{~N}-4.4 \mathrm{P}-11.6 \mathrm{~K}$, with the same irrigation and fertigation regime as in 2012 at this location. Weed control was achieved with trifluralin (Albaugh, Ankeny, IA) preplant at 0.9 and $0.3 \mathrm{~L} \cdot \mathrm{ha}^{-1}$ posttransplant. All other cultural conditions were identical to those used in Summerton 2012 trial.

All plot and individual head data including mean days from transplanting to mean harvest day (DTH) were recorded for each environment. Head traits were averaged using all individual head measurements or ratings and this served as a plot mean. Data were analyzed using PROC GLM of SAS (version 9.2; SAS Institute, Cary, NC). Least significant differences (i.e., Fisher's protected least significant difference test) for specific traits or yield components were computed only if a significant treatment effect was indicated by analysis of variance.

\section{Results}

No significant differences in mean head weight, mean stem diameter, or bead size rating were observed among treatments in the 2012 Summerton trial where the hybrid 'Emerald Crown' was grown (Table 1 ). However, there were significant $(P<$ 0.01 ) differences in mean bead uniformity ratings in this environment. For this trait, each spacing treatment was significantly different from the others with ratings for the 4-, 6-, and 8-inch within-row spacing treatments having a bead uniformity of $3.0,3.5$, and 3.7 , respectively (Table 1). Thus, as spacing increased, so did relative bead uniformity. The percentage of the transplanted population that made marketable heads was significantly $(P<0.05)$ affected by within-row spacing with the 6- and 8-inch spacing treatments and was greater (e.g., $86 \%$ and $83 \%$ vs. $65 \%$ ) than the 4 -inch treatment (Table 1). Total marketable yield was higher $(P<0.05)$ for the 4 - and 6 -inch spacing treatments when compared with the 8 -inch treatment. Mean total marketable yields at the 4-, 6-, and 8 -inch spacing treatments were 19,861 , 17,686 , and $13,957 \mathrm{~kg} \cdot \mathrm{ha}^{-1}$, respectively (Table 1). Mean days from transplant to mean harvest day in the Summerton 2012 trial was highly significant $(P<$ 0.001 ) with the 4 -inch spacing treatment taking $13.2 \mathrm{~d}$ longer to mature than the 6- and 8-inch spacings.

In the 2013 trial at Charleston, there were no differences in mean head weight or stem diameter of 'Emerald Crown' heads among the three within-row spacing treatments (Table 1). Nearly all head weights were greater than $200 \mathrm{~g}$ and stem diameters were $\approx 34 \mathrm{~mm}$, independent of plant spacing. Unlike the results from the previous year at Summerton, there were no differences among spacing treatments for bead uniformity, but there were significant differences for bead size $(P<0.05)$ that increased with spacing. With this trait, greater within-row spacing was associated with slightly smaller beads (Table 1). Total marketable yield in this trial significantly increased $(P<$ $0.01)$ as within-row spacing decreased with the 4 -inch treatment exhibiting the highest yield of $13,341 \mathrm{~kg} \cdot \mathrm{ha}^{-1}$. The percentage of the established population producing marketable heads followed a trend opposite to that observed for marketable yield $(P<0.01)$; the greatest marketable head percentages occurred with the wider within-row spacing. At 8 inches, $84 \%$ of plants produced a marketable head, whereas only $57 \%$ of plants did at the 4 -inch treatment. It is noteworthy that even though this percentage of marketable heads was lower at the most dense populations, marketable yields were still significantly higher in those treatments. Days to harvest for 'Emerald Crown' in the Charleston 2013 environment were different $(P<0.05)$ with the 4 -inch within-row spacing taking 2 to $3 \mathrm{~d}$ longer to mature than the 6 - and 8 -inch spacing treatments.

There were no effects of spacing on bead uniformity, bead size, and stem diameter of 'Durapak 19' also grown in the Charleston 2013 trial

Table 1. Treatment means for bead size, bead uniformity, stem diameter, head weight, percentage of plants with marketable heads, and total marketable yields for 'Emerald Crown' broccoli as affected by within-row spacing in trials at Summerton, SC, in 2012 and 2013, and at Charleston, SC, in 2013.

\begin{tabular}{|c|c|c|c|c|c|c|c|c|}
\hline \multirow[b]{2}{*}{ Environment } & \multirow{2}{*}{$\begin{array}{l}\text { Within-row } \\
\text { spacing } \\
\text { (inches) }^{z}\end{array}$} & \multirow{2}{*}{$\begin{array}{c}\text { Plant } \\
\text { population } \\
{\text { (plants } / \mathrm{ha})^{\mathrm{z}}}^{\text {pland }}\end{array}$} & $\begin{array}{c}\text { Bead } \\
\text { uniformity } \\
{\text { (1-5 scale })^{\mathrm{y}}}\end{array}$ & $\begin{array}{c}\text { Bead size } \\
(1-5 \text { scale })^{x}\end{array}$ & $\begin{array}{c}\text { Stem } \\
\text { diam } \\
(\mathbf{m m})^{\mathrm{z}}\end{array}$ & $\begin{array}{l}\text { Head wt } \\
(\mathrm{g} / \text { head })^{\mathrm{z}}\end{array}$ & $\begin{array}{l}\text { Plants with } \\
\text { marketable } \\
\text { heads }(\%)\end{array}$ & $\begin{array}{c}\text { Total } \\
\text { marketable } \\
\text { yield }\left(\mathrm{kg} \cdot \mathrm{ha}^{-1}\right)^{\mathrm{z}}\end{array}$ \\
\hline & & & \multicolumn{6}{|c|}{ 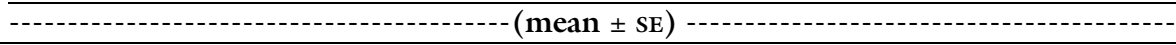 } \\
\hline Summerton & 4 & 108,000 & $3.0 c^{\mathrm{w}} \pm 0.3$ & $2.9 \pm 0.2$ & $41.1 \pm 5.6$ & $278.3 \pm 24.3$ & $65 \mathrm{~b} \pm 5.7$ & $19,861 \mathrm{a} \pm 808$ \\
\hline \multirow[t]{2}{*}{2012} & 6 & 72,000 & $3.5 \mathrm{~b} \pm 0.3$ & $3.0 \pm 0.1$ & $39.1 \pm 1.1$ & $286.3 \pm 37.3$ & $86 \mathrm{a} \pm 2.6$ & $17,686 \mathrm{a} \pm 2,885$ \\
\hline & 8 & 54,000 & $3.7 \mathrm{a} \pm 0.2$ & $3.0 \pm 0.1$ & $38.1 \pm 1.2$ & $313.2 \pm 19.2$ & $83 \mathrm{a} \pm 4.4$ & $13,957 b \pm 1,260$ \\
\hline Charleston & 4 & 108,000 & $3.9 \pm 0.1$ & $3.5 b \pm 0.1$ & $34.6 \pm 0.4$ & $216.3 \pm 7.1$ & $57 \mathrm{c} \pm 1.2$ & 13,341 a \pm 519 \\
\hline \multirow[t]{2}{*}{2013} & 6 & 72,000 & $3.9 \pm 0.1$ & $3.6 b \pm 0.1$ & $34.5 \pm 1.1$ & $218.3 \pm 17.8$ & $74 \mathrm{~b} \pm 4.6$ & $11,586 b \pm 1,014$ \\
\hline & 8 & 54,000 & $3.9 \pm 0.1$ & $3.8 \mathrm{a} \pm 0.0$ & $33.3 \pm 0.5$ & $205.0 \pm 6.1$ & $84 \mathrm{a} \pm 2.2$ & $9,304 c \pm 478$ \\
\hline Spacing effect & & & NS & * & NS & NS & ** & $* *$ \\
\hline
\end{tabular}

${ }^{\mathrm{z}} \mathrm{l}$ inch $=2.54 \mathrm{~cm} ; \mathrm{l}$ plant $/ \mathrm{ha}=0.4047$ plant $/$ acre $\mathrm{l} \mathrm{mm}=0.0394 \mathrm{inch} ; \mathrm{l} \mathrm{g}=0.0353 \mathrm{oz} ; \mathrm{l} \mathrm{kg} \cdot \mathrm{ha}^{-1}=0.8922 \mathrm{lb} / \mathrm{acre}$.

${ }^{\mathrm{y}} \mathrm{l}=$ very poor uniformity; 3 = average to good uniformity; 5 = excellent uniformity.

${ }^{\mathrm{x}} \mathrm{l}=$ greater than $1.75 \mathrm{~mm}$ diameter; $3=1.25$ to $1.5 \mathrm{~mm}$ diameter; $5=$ less than $1.0 \mathrm{~mm}$ diameter.

"Means followed by a different letter are significantly different based on the protected least significant difference (Fisher's $F$ test following analysis of variance found significant at $P<0.05)$. A nonsignificant $F$ test is represented by Ns. ${ }^{*},{ }^{* *}$ Indicates significant spacing effect at $P<0.05$ or 0.01 , respectively. 
(Table 2). Head weight was significantly $(P<0.05)$ affected by withinrow spacing with the 6-inch spacing treatment having the greatest mean head weight (219.4 g); however, head weight $(211.1 \mathrm{~g})$ at the 4 -inch spacing treatment was not significantly different from that at the 6 -inch treatment (Table 2). Interestingly, the widest plant spacing resulted in the lowest mean head weight (191.2 g) for 'Durapak 19'. Total marketable yield for 'Durapak 19' increased $(P<$ $0.01)$ as within-row spacing decreased with the 4 -inch treatment exhibiting the highest yield of $16,617 \mathrm{~kg} \cdot \mathrm{ha}^{-1}$. Similar to the hybrid 'Emerald Crown' in Charleston 2013, the percentage of the population producing marketable heads exhibited the opposite trends observed for yield $(P<0.01)$. The greatest marketable percentages occurred with the wider within-row spacing of 8 inches. With this treatment, $91 \%$ of plants produced marketable heads compared with $73 \%$ of plants in the 4 -inch spacing treatment. Once again, it is noteworthy that even though the percentage of marketable heads was lower at the most dense populations, yields were still significantly higher in those treatments. There was no difference in DTH among the spacing treatments in the Charleston 2013 trial with the hybrid 'Durapak 19'.

No differences in total marketable yield, mean head weight, mean stem diameter, or bead uniformity ratings were observed among treatments in the 2013 Summerton trial where the hybrid 'Emerald Crown' was grown (Table 1). However, there were significant $(P<0.01)$ differences in mean bead size rating in this environment. There were no differences in bead size between the 6- and 8-inch within-row spacing treatments, but these two treatments had significantly smaller beads than did the heads at 4 inches (Table 1). Mean head weights were similar to those observed in Summerton 2012 with means for this trait typically being $>250.0$ g. Similar to Charleston 2013, a higher percentage of the population in Summerton 2013 produced marketable heads $(P<0.05)$ at the wider within-row spacing of 8 inches. With this treatment, $53 \%$ of plants produced marketable heads, whereas only $33 \%$ of plants did so in the 4-inch spacing treatment. A higher percentage of marketable heads were produced by plants in the wider spacing treatments, but total marketable yields, although not significant, were still higher at the most dense spacing. There were no differences in DTH among the spacing treatments in the Summerton 2013 environment.

\section{Discussion}

Eastern vegetable growers have typically used lower plant densities than those tested in this study. This may be largely due to the recommendations made by eastern researchers (i.e., Dufault and Waters 1985; Schellenberg et al., 2009). Several earlier studies evaluating plant density effects on broccoli production were done several decades ago when higher populations were being tested for western production systems (Cutcliffe, 1971, 1975; Palevitch, 1970). All of those studies, as well as others reported somewhat later (Kahn et al., 1991; Salter et al., 1984), made use of early hybrids that are no longer available and are effectively obsolete based on modern standards. In addition, in almost all of the above reports, the target broccoli product was a relatively small single head suitable for bunching in groups of three or more heads. Broccoli heads harvested from differing spacing treatments of this study were not significantly different for head weight or stem diameter (Tables 1 and 2). Although these traits did vary between the different environments, they generally did not vary among treatments within environments. Mean head weights were all at least $200 \mathrm{~g}$, and generally below $300 \mathrm{~g}$; mean stem diameters ranged from 31 to $41 \mathrm{~mm}$. Even by doubling plant density (e.g., reducing withinrow spacing from 8 to 4 inches), a significant reduction of head weight and stem diameter was not observed.

Two quality criteria (bead size and bead uniformity) rated on a 1 to 5 scale that were examined in the trials showed variable responses to the spacing differences. Bead size did not vary significantly among treatments for 'Emerald Crown' in Summerton 2012 or for 'Durapak 19' in Charleston 2013, but these traits did differ significantly in the other two trials (Tables 1 and 2). In those cases, the more dense spacing treatments resulted in larger bead size. It is noteworthy that the numerical differences (e.g., 3.5 vs. 3.8 ) would be difficult to distinguish as a visual rating on a head by head basis. Significant differences in bead uniformity were only observed in one environment in Summerton 2012, where 'Emerald Crown' had lower uniformity at the closest spacing. On the basis of the overall results from three environments, we conclude

Table 2. Treatment means for bead size, bead uniformity, stem diameter, head weight, percentage of plants with marketable heads, and total marketable yields for 'Durapak 19' broccoli as affected by within-row spacing in trials at Charleston, SC, in 2013 .

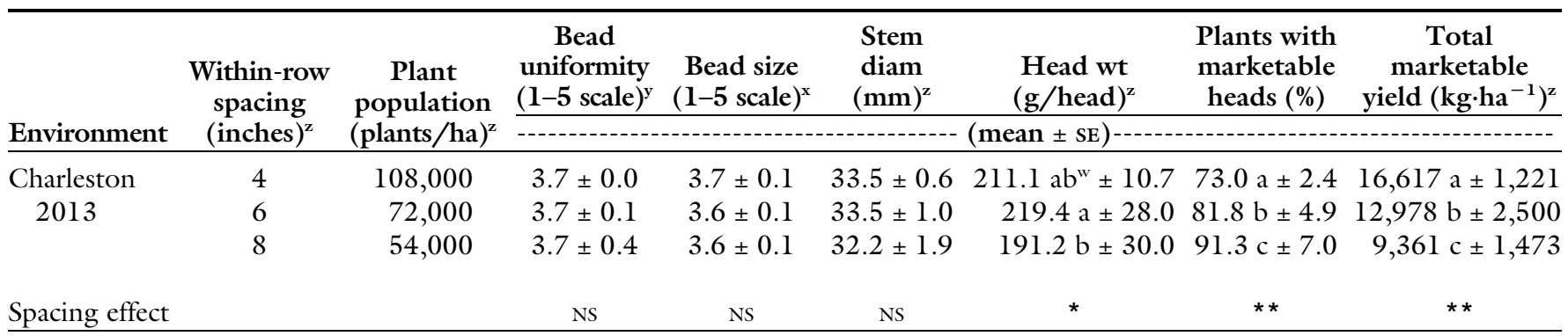

${ }^{\mathrm{z}} \mathrm{l}$ inch $=2.54 \mathrm{~cm} ; \mathrm{l}$ plant $/ \mathrm{ha}=0.4047 \mathrm{plant} / \mathrm{acre} ; \mathrm{l} \mathrm{mm}=0.0394 \mathrm{inch} ; \mathrm{l} \mathrm{g}=0.0353 \mathrm{oz} ; \mathrm{l} \mathrm{kg} \cdot \mathrm{ha}^{-1}=0.8922 \mathrm{lb} / \mathrm{acre}$

${ }^{\mathrm{y}} 1$ = very poor uniformity; 3 = average to good uniformity; 5 = excellent uniformity.

${ }^{\mathrm{x}} \mathrm{l}=$ greater than $1.75 \mathrm{~mm}$ diameter; $3=1.25$ to $1.5 \mathrm{~mm}$ diameter; $5=$ less than $1.0 \mathrm{~mm}$ diameter

"Means followed by a different letter are significantly different based on the protected least significant difference (Fisher's $F$ test following analysis of variance found significant at

$P<0.05)$. A nonsignificant $F$ test is represented by Ns. ${ }^{*},{ }^{\star *}$ Indicates significant spacing effect at $P<0.05$ or 0.01, respectively. 
Table 3. Mean maturity as measured by the number of days from transplant to mean harvest day (DTH) of 'Emerald Crown' broccoli relative to within-row spacing at Summerton, SC, in 2012 and 2013 and at Charleston, SC, in 2013, and also of 'Durapak 19' in Charleston, SC, in 2013.

\begin{tabular}{|c|c|c|c|c|c|}
\hline \multicolumn{6}{|c|}{ Within-row spacing (inches) ${ }^{\mathrm{z}}$} \\
\hline \multirow[b]{2}{*}{ Environment } & & 4 & 6 & 8 & \multirow[b]{2}{*}{ Spacing effec } \\
\hline & Hybrid & \multicolumn{3}{|c|}{ Maturity [mean \pm SE $(\mathrm{DTH})]$} & \\
\hline Charleston 2013 & Emerald Crown & $71.6 \mathrm{a} \pm 0.1$ & $69.5 \mathrm{~b} \pm 0.8$ & $69.1 b \pm 1.6$ & * \\
\hline Summerton 2013 & Emerald Crown & $70.5 \pm 5.8$ & $69.3 \pm 3.7$ & $67.0 \pm 2.4$ & NS \\
\hline Charleston 2013 & Durapak 19 & $86.6 \pm 0.9$ & $85.7 \pm 1.3$ & $85.4 \pm 1.1$ & NS \\
\hline
\end{tabular}

${ }^{\mathrm{z}} 1$ inch $=2.54 \mathrm{~cm}$.

'Means followed by a different letter are significantly different based on the protected least significant difference (Fisher's $F$ test following analysis of variance found significant at $P<0.05)$. A nonsignificant $F$ test is represented by Ns. ${ }^{\star \star \star *}$ Indicates significant spacing effect at $P<0.05$ or 0.001 , respectively.

that quality traits of harvested heads were minimally impacted by the variable spacings. These conclusions are similar to those made by Chung (1982) who found that increased plant density had little effect on bead size and bead uniformity. In addition, Jett et al. (1995) found no significant differences in head quality of withinrow spacings ranging from 6 to 18 inches, respectively.

We observed the greatest percentage of plants producing marketable heads at the 8 -inch spacing in two out of three environments. However, total marketable yields were always lowest in this treatment. There could be a higher risk of plants failing to produce marketable heads in the more dense spacings, yet this risk may be necessary to maximize yields. The more dense spacings may also delay maturity (Table 3 ), but this may only be a problem if harvest conditions become less favorable during the later harvest period. This scenario contributed to yield losses in Summerton Fall 2013, where freezing temperatures occurred over numerous nights as heads were maturing, effectively reducing quality and the percentage of plants harvested in all treatments. The unique conditions that occurred in this environment likely explain an inability to differentiate spacing effects on yield in this trial.

Atallah and Gomez (2013) have suggested that broccoli yields greater than $10,000 \mathrm{~kg} \cdot \mathrm{ha}^{-1}$ are needed for eastern broccoli growers to be competitive with western producers. In trials described herein, the 4- and 6-inch spacing treatments produced estimated yields consistently greater than 10,000 $\mathrm{kg} \cdot \mathrm{ha}^{-1}$. Although the 4 -inch withinrow spacing produced significantly higher yields at two out of three environments, broccoli harvested from the 6 -inch within-row spacing treatments tended to exhibit better quality heads. In addition, a higher percentage of plants produced marketable heads in the 6-inch treatment compared with the 4 -inch treatment. These observations, as well as a potential delay in maturity with the most-dense plantings, indicate that the 6 -inch spacing may have some advantages over the 4-inch spacing treatment.

Western broccoli producers typically grow broccoli with population densities between 100,000 to 200,000 plants/ha. Results from this study indicate that densities greater than 100,000 plants/ha may be used by eastern producers to achieve competitive yields of high-quality crown-cut broccoli. However, because of increased cost of production and associated risk of the 4-inch vs. 6-inch within-row spacing, growers are recommended to try small acreages of both densities and determine optimal densities for their location.

\section{Literature cited}

Atallah, S.A. and M.I. Gomez. 2013. Eastern broccoli crop budgets. Cornell Univ. Ext. Bul. EB-2013-14. 15 Dec. 2014. <http://dyson.cornell.edu/ outreach/extensionpdf/2013/CornellDyson-eb1314.pdfs.

Chung, B. 1982. Effects of plant density on the maturity and once over harvest yields of broccoli. J. Hort. Sci. 57:365-372.

Cutcliffe, J.A. 1971. Effects of plant population, nitrogen, and harvest date on yield and maturity of single-harvested broccoli. HortScience 6:482-484.

Cutcliffe, J.A. 1975. Effect of plant spacing on single-harvest yields of several broccoli cultivars. HortScience 10:417-419.

Dufault, R.J. and L. Waters, Jr. 1985. Interaction of nitrogen fertility and plant populations on transplanted broccoli and cauliflower yields. HortScience 20:127-128.
Farnham, M., T. Björkman, D. Coulliard, Z.W. Shail, Z. Stansell, W. Morris, A. Hamilton, J. Davis, J.P. Smith, M. Hutton, and P.D. Griffiths. 2011. Broccoli evaluation scale. 15 Dec. 2014. <https:// archive.org/details/ScoringChart>.

Farnham, M.W. and M.A. Grusak. 2014. Assessing nutritional changes in a vegetable over time: Issues and considerations. HortScience 49:128-132.

Jett, L.W., R.D. Morse, and C.R. O'Dell. 1995. Plant density effects yield and quality of broccoli under different environments. HortScience 30:50-52.

Kahn, B.A., P.G. Shilliüg, G.H. Brusewitz, and R.W. Mc New. 1991. Force to shear the stalk, stalk diameter, and yield of broccoli in response to nitrogen fertilization and within-row spacing. J. Amer. Soc. Hort. Sci. 116:222-227.

Le Strange, M., M.D. Cahn, S.T. Koike, and R.F. Smith. 2010. Broccoli production in California. Univ. California Davis Publ. 7211. 15 Dec. 2014. <http:// anrcatalog.ucdavis.edu/pdf/7211.pdfs.

Palevitch, D. 1970. Effects of plant population on yield of broccoli (Brassica oleracea var. italica) in single harvest. HortScience 5:230-231.

Salter, P.J., D.J. Andrews, and J.M. Akehurst. 1984. The effects of plant density, spatial arrangement and sowing date on yield and head characteristics of a new form of broccoli. J. Hort. Sci. 59:79-85.

Schellenberg, D.L., A.D. Bratsch, and Z. Shen. 2009. Large single head broccoli yield as affected by plant density, nitrogen, and cultivar in a plasticulture system. HortTechnology 19:792-795.

U.S. Department of Agriculture. 1999. Crop profile for broccoli in California. Crop profile/PMSP. 15 Dec. 2014. <http:// www.ipmcenters.org/cropprofiles/docs/ cabroccoli.pdf>.

U.S. Department of Agriculture. 2014. Vegetables final estimates 2008-2012. U.S. Dept. Agr., Natl. Agr. Stat. Serv., Stat. Bul. 1033. 